\title{
Effectiveness of ethical issues teaching program on knowledge, ethical behavior and ethical stress among nurses
}

\author{
Abeer M. Zakaria ${ }^{1}$, Wafaa F. Sleem ${ }^{* 1}$, Abeer Mohamed Seada ${ }^{2}$ \\ ${ }^{1}$ Nursing Administration, Nursing Faculty, Mansoura University, Egypt \\ ${ }^{2}$ Nursing Administration, Nursing Faculty, Cairo University, Egypt
}

Received: January 3, 2016

DOI: $10.5430 /$ jnep.v6n7p125

\author{
Accepted: February 16, 2016 \\ Online Published: March 24, 2016 \\ URL: http://dx.doi.org/10.5430/jnep.v6n7p125
}

\begin{abstract}
Background: Innovations and technology, scarce resources and conflicting values have set expectations for nurses' ethical competence. Daily ethical issues in nursing practice attract little attention but can create stress for nurses. The aim of the study is to examine the effect of teaching program regarding ethical issues on nurses' knowledge, ethical behavior, frequency and degree of ethical stress.

Subjects and methods: The study was conducted among staff nurses working at Mansoura Emergency Hospital which provides a wide spectrum of health services at Delta Region by using A Quasi-experimental design. Three tools were used for data collection namely: Ethical Issues Knowledge Questionnaire, Observational checklist for Ethical Behavior and Ethical Issues Stress scale.

Results: The study findings conclude that there was a strong correlation between Knowledge of Nursing ethics and Ethical behavior after the teaching program. In addition strong correlation found between the Knowledge and frequency of ethical stress in post test.

Conclusion \& recommendations: Ethical issues teaching program has positive influence in improving their knowledge, reduction in the frequency and degree of stress. It is recommended that ethics training cannot take place just once in a training room, but needs on-going support at all levels of the organization. The training should include what ethics is, along with actual examples of relevant situations, and how to explore an ethical dilemma through interacting with others.
\end{abstract}

Key Words: Ethical behavior, Ethical issues, Ethical stress, Teaching Program

\section{INTRODUCTION}

In the past two decades, healthcare organizations have focused their interest on nurses' and other healthcare professionals' ethical competence. Recently, international and national associations have set up goals for healthcare organizations in ensuring ethical competence. ${ }^{[1,2]}$ The Global Com- petency Model of the World Health Organization (WHO) emphasizes professional behavior in accordance with healthcare ethics and values. ${ }^{[3]}$ Internationally, nursing is guided by human rights, healthcare legislation and ethical guidelines in nursing. ${ }^{[4]}$

The principles of ethics included respect for persons/autoEgypt.

*Correspondence: Wafaa F. Sleem; Email: dr_wafaasleem@yahoo.com; Address: Nursing Administration, Nursing Faculty, Mansoura University,

Published by Sciedu Press 
nomy, beneficence, non-maleficence, fairness, veracity, fidelity and confidentiality. ${ }^{[5]}$ The concept of autonomy is an important extension of this principle. You act autonomously when your actions are the result of your own deliberation and choices. The principle of non-maleficence states that we should act in ways that do not inflict evil or cause harm to others. The principle of beneficence is often simply stated as an obligation to act in ways that promote good. Veracity is the principle oftruth telling. The principle of fidelity broadly requires that we act in ways that are loyal. While a general principle of justice requires that we act in ways that treat people equitably and fairly. ${ }^{[6]}$

While the current health care environment invariably raises ethical issues and dilemmas for all health professional including nurses. ${ }^{[7,8]}$

Nurses everywhere have long struggled with ethical challenges in patient care. In fact, in Florence Nightingale's Notes on Nursing, she discussed ethical duties of confidentiality, communication, and the centrality of meeting patients' needs. ${ }^{[9,10]}$

Ethical issues present significant challenges in today's practice environment. As technology changes and makes possible what was once impossible, building the nursing expertise to anticipate and manage the ethical questions that result is often overlooked. ${ }^{[1]}$ Moreover advances in medical technology allow for better recovery for critically ill patients and dramatically extend the human life span. However, while advances bring benefits to patients and families, they simultaneously raise moral and ethical issues regarding respect for patient integrity and autonomy, soaring medical costs, quality care, and end-of-life decision making. ${ }^{[12]}$

Researchers identify the ethical issues that nurses face as: advance directive, do not resuscitate orders, documentation and patient privacy ,informed consent, medication errors and pain management. ${ }^{[12,13]}$ Moreover (Redman and fry, 2000) identified main ethical issues in particular role or setting, harm/good of life prolonged aggressive therapies, inadequacy of resources, under treatment, consent, and refusal of treatment, disagreement with quality of medical care and protection of child's rights. ${ }^{[14]}$

An ethical issue can occur in any healthcare situation where profound moral questions of "rightness" or "wrongness" underlie professional decision-making and the beneficent care of patients. Understandably, all members of the healthcare team, including nurses, can be affected by ethical decisions as they address the stressful and sometimes exhausting nature of working through ethical problems. ${ }^{[15]}$

Fostering and developing ethically competent nursing prac- tice is an essential aspect of nursing education. In order to encourage nurses' moral development, reasoning and behavior, it is important that nurse educators recognize the unique problems and challenges they experience. ${ }^{[16]}$

Although nursing schools have become more concerned with the ethical development of their students, researchers point out that education has not reflected reality and does not prepare newly qualifying nurses to deal effectively with a variety of ethical situations in the health care setting. ${ }^{[6]}$ The traditional ethics education has tended to emphasize the acquisition of philosophical and theoretical knowledge and has created a gap between theory and practice. New approaches are needed for teaching nursing ethics pragmatically. ${ }^{[6]}$

It is a general conception that ethic education nurses get during their professional education and training plays a significant role in the enhancement of their moral sensitivity. Education of ethics is a process aiming to enable the professionals working in the healthcare field to conceive the role of moral values in their relations with individuals to whom they serve, the society they live in, colleagues, and other healthcare disciplines and the significance of such values in their professional identity. ${ }^{[17,18]}$

\subsection{Significance of the study}

Nurses play a role as advocating to assist patients and families struggling with complex information and difficult decisions. In particular, the fact that nurses encounter clinical situations that require ethical judgment highlights the need for nursing staff to gain knowledge and expertise in delivering care in an ethical manner. ${ }^{[12]}$ Increased work complexity and financial strain in the health care sector have led to higher demands on staff to handle ethical issues. These demands can elicit stress reactions, that is, moral distress. One way to support professionals in handling ethical dilemmas is education and training in ethics. ${ }^{[19]}$

\subsection{Study aim}

To examine the effect of teaching program regarding ethical issues on Knowledge, ethical behavior, and ethical stress among nurses.

\subsection{Study hypotheses}

There is significant difference in the knowledge regarding ethical issues, ethical behavior and ethical stress before and after the participation in an ethical issues teaching program among nurses.

\section{SubJects \& METhods}

\subsection{Design}

A Quasi-experimental design was utilized. 


\subsection{Setting}

The study was conducted at Mansoura Emergency Hospital which is affiliated to Mansoura University Hospitals, Mansoura City, Egypt that provides a wide spectrum of health services at Delta Region. This hospital receives emergency cases and injuries 3 days/week from Mansoura City and other near areas, giving care for about 5 million people, according to the hospital most recent statistical data. The hospital occupied with (180) beds.

\subsection{Subjects}

Staff nurses working in different department of Mansoura University Emergency Hospital. The sample was taken through a proportionate random sampling technique and the Sample size is estimated with a $20 \%$ precision and confidence level $95 \%$. The ideal sample size was 70 staff nurses at work.

\subsection{Tools of data collection}

Three tools were employed in this study:

Tool (1): Ethical Issues Knowledge Questionnaire. This tool was developed by the researchers based on scientific literature, ${ }^{[20-22]}$ it is aimed to assess nurses' knowledge related to ethical issues which included two parts:

(Part 1): Include demographic variables characteristics of the staff nurses as: age, department, educational qualification, experience.

(Part 2): Ethical Issues Knowledge Questionnaire sheet: presents the ethical issues that confront nurses during their work settings related to ethical principles. It consisted of (14) Multiple-choice questions, covering ethical principles such as beficence ( 2 items), informed consent ( 2 items), autonomy ( 2 items), veracity ( 3 items), justice ( 2 items), fidelity ( 2 items), confidentiality (1 item).

The scoring system for the questionnaire sheet consisted of giving a score of one for the correct answer and zero for the wrong answer for Multiple-choice questions. The scoring levels were arranged as follow $60 \%$ and more for adequate knowledge. Less than $60 \%$ is for inadequate knowledge. ${ }^{[23]}$

Tool (2): Ethical behavior observational sheet. This tool was developed based on the ethical principles and responsibilities of nurses of the Turkish Nurses ${ }^{[24]}$ and on regulation on patient rights of the ministry of health ${ }^{[25]}$ to evaluate nurses' practice about ethical behavior. It consisted of 33 statements covering some areas related to ethical behavior such as non-maleficence and beneficence (6 statements), autonomy (9 statements), justice (4 statements), confidentiality and secrecy (7 statements), and professional responsibility ( 7 statements). The nurses' responses 1, 2, 3, 4 for never, rarely, usually, always respectively.

Tool (3): Ethical Issues Stress Scale: Based on literature ${ }^{[15,26]}$ and aimed to measure nurses direct involvement with ethical issues in their healthcare practice.

The tool contained two sets of 15 items, aimed to measure the frequency of ethical issues that the respondent encounters and the ethical stress associated with each issue.

Items included on a 3 -point Likert scale from 1 (never) to 3 (daily), respondents were asked to indicate the frequency of their involvement with each of the specific issues over the previous year.

Stress associated with each item was measured on a 3-point Likert scale ranging from 1 (no stress) to 3 (very high stress). Higher scores (more than 50\%) indicated higher frequency of involvement with each specific ethical issue, as well as higher level of stress.

\subsection{Methods}

\section{Ethical consideration}

Before commencing the study, ethical approval was granted from the research ethics' committee in which the study took place. The researchers ensured that the correct procedures were undertaken concerning informed consent, autonomy, anonymity and maintenance of the subjects of confidentiality.

Official permission to conduct the study was obtained from the manager of hospital and administrator of training department at Mansoura Emergency Hospital.

Ethical issues knowledge questionnaire which was developed by the researchers were tested for its content validity by 5 faculty members from Mansoura faculty of nursing.

Stress of Ethical Issues Scale was translated by the researchers into Arabic, and tested for its content validity and relevance by five experts in nursing administration from faculties of nursing, and accordingly the necessary modification was done.

Double translation English-Arabic was done separately to ensure validity of tools.

Internal consistency reliability of the three tools items were assessed using coefficient alpha. It was 0.96 for (tool 1) items while it was 0.97 for (tool 2) items and 0.82, 0.89 for two sets of (tool 3) respectively.

A pilot study was conducted on $10 \%$ of study sample ( $\mathrm{n}=$ 7) to examine its clarity and feasibility before using it. All nurses involved in the pilot study were excluded from the study sample.

Informed consent for participation in the study was secured 
from the entire study sample. Participation in the research is voluntary. Each participant may decide to stop completing the study and withdraw at any time without consequence.

The designed educational program includes the following sessions: objectives of the ethical teaching program, concept of ethics, nursing code of ethics, ethical dilemma, ethical decision making, principle, ethical and legal aspects in nursing, how to prevent ethical and legal problems in nursing.

Before implementation of the program the knowledge test questionnaires as well as stress of ethical issues scale were provided to nurses on their work place at the morning shift and Also observation of nurse's ethical behavior. The previous instruments were utilized during different period the program. The time needed by each staff nurse to complete each sheet ranged from 25-30 minutes.

The program was implemented by researchers four times for four groups of nurses according to the working place of each group. The total allocated time for achieving the whole program to each group was 16 hours ( 8 sessions $\times 2$ hours).

Different teaching and learning methods were used during the sessions included: interactive lecture, group discussion, demonstration, brain storming, work in small groups.

Table 1. Demographic variables of study subjects $(\mathrm{N}=70)$

\begin{tabular}{lll}
\hline Demographic variables & Frequency (N) & \% \\
\hline Age (Years) & 5 & 7.1 \\
$\quad$ Less than 25 & 16 & 22.9 \\
$25-30$ & 19 & 27.1 \\
$31-36$ & 30 & 42.9 \\
$\quad$ More than 36 & & \\
Department & 5 & 7.1 \\
$\quad$ Neurological Unit & 5 & 7.1 \\
ENT Unit & 14 & 20 \\
Surgical Unit & 21 & 30 \\
Orthopaedic Unit & 4 & 5.7 \\
Cosmetic Unit & 4 & 5.7 \\
Operating room & 13 & 18.6 \\
Casualty and Emergency Unit & 1 & 1.4 \\
Infection control & 1 & 1.4 \\
Cardio vascular Unit & 2 & 2.9 \\
ICU new & & \\
Qualification & 6 & 8.6 \\
$\quad$ Nursing technical institute & 64 & 91.4 \\
Nursing diploma & & \\
Experience (Year) & 1 & 1.4 \\
Less than 1 & 9 & 12.9 \\
1-10 & 47 & 67.1 \\
11-20 & 13 & 18.6 \\
More than 20 & & \\
\hline & & \\
\hline
\end{tabular}

\subsection{Statistical design}

Analysis was done using Statistical Package for Social Science (SPSS), version 16.0. Data are summarized using:
Arithmetic mean: as average describing the central tendency of observations.

Table 2. Distribution of Nurses according to their level of knowledge on Ethical issues during different periods of program $(\mathrm{N}=70)$

\begin{tabular}{|c|c|c|c|c|c|c|}
\hline \multirow{2}{*}{$\begin{array}{l}\text { Level of } \\
\text { Knowledge on } \\
\text { ethical issues }\end{array}$} & \multicolumn{2}{|c|}{$\begin{array}{l}\text { Pre } \\
\text { program }\end{array}$} & \multicolumn{2}{|c|}{$\begin{array}{l}\text { Immediately } \\
\text { Post } \\
\text { program }\end{array}$} & \multicolumn{2}{|c|}{$\begin{array}{l}3 \text { months Post } \\
\text { program }\end{array}$} \\
\hline & No & $\%$ & No & $\%$ & No & $\%$ \\
\hline \multicolumn{7}{|l|}{ Beneficence } \\
\hline Adequate & 28 & 40 & 58 & 82.9 & 36 & 51.4 \\
\hline Non-adequate & 42 & 60 & 12 & 17.1 & 34 & 48.6 \\
\hline \multicolumn{7}{|l|}{ Consent } \\
\hline Adequate & 12 & 17.1 & 35 & 50 & 23 & 32.9 \\
\hline Non-adequate & 58 & 82.9 & 35 & 50 & 47 & 67.1 \\
\hline \multicolumn{7}{|l|}{ Autonomy } \\
\hline Adequate & 47 & 67.1 & 70 & 100 & 66 & 94.3 \\
\hline Non-adequate & 23 & 32.9 & 0 & 0 & 4 & 5.7 \\
\hline \multicolumn{7}{|l|}{ Veracity } \\
\hline Adequate & 19 & 27.1 & 70 & 100 & 34 & 48.6 \\
\hline Non-adequate & 51 & 72.9 & 0 & 0 & 36 & 51.4 \\
\hline \multicolumn{7}{|l|}{ Justice } \\
\hline Adequate & 23 & 32.9 & 70 & 100 & 70 & 100 \\
\hline Non-adequate & 47 & 67.1 & 0 & 0 & 0 & 0 \\
\hline \multicolumn{7}{|l|}{ Fidelity } \\
\hline Adequate & 2 & 2.9 & 69 & 98.6 & 59 & 84.3 \\
\hline Non-adequate & 68 & 97.1 & 1 & 1.4 & 11 & 15.7 \\
\hline \multicolumn{7}{|l|}{ Total Score } \\
\hline Adequate & 59 & 84.3 & 70 & 100 & 70 & 100 \\
\hline Non-adequate & 11 & 15.7 & 0 & 0 & 0 & 0 \\
\hline
\end{tabular}

The Standard Deviation: as a measure of dispersion of results around the mean (for quantitative variables). The number of observations: for each the percentage (for qualitative variables).

Qualitative variables were compared using $\chi^{2}$ test, and $T$ test, while correlation coefficient $(r)$ is used to measure the strength of a linear association between two variables.

Table 3. Mean scores of Nurses about Ethical behaviour during different periods of program $(\mathrm{N}=70)$

\begin{tabular}{|c|c|c|c|c|c|}
\hline \multirow{2}{*}{$\begin{array}{l}\text { Areas of Ethical } \\
\text { Behaviour }\end{array}$} & \multirow{2}{*}{\begin{tabular}{|l|}
$\begin{array}{l}\text { Pre } \\
\text { program }\end{array}$ \\
Mean \pm \\
SD
\end{tabular}} & \multicolumn{2}{|c|}{$\begin{array}{l}\text { Immediately Post } \\
\text { program }\end{array}$} & \multicolumn{2}{|c|}{3 months Post program } \\
\hline & & $\begin{array}{l}\text { Mean } \pm \\
\text { SD }\end{array}$ & $\begin{array}{l}\text { Paired } \\
\text { 't'-value }\end{array}$ & $\begin{array}{l}\text { Mean } \pm \\
\text { SD }\end{array}$ & $\begin{array}{l}\text { Paired } \\
\text { 't'-value }\end{array}$ \\
\hline $\begin{array}{l}\text { Non maleficence } \\
\text { and beneficence }\end{array}$ & $2.15 \pm 0.63$ & $3.49 \pm 0.41$ & $\begin{array}{l}\mathrm{T}=11.8 \\
P=.000^{* *}\end{array}$ & $3.34 \pm 0.36$ & $\begin{array}{l}\mathrm{T}=14.4 \\
P=0.000^{* *}\end{array}$ \\
\hline $\begin{array}{l}\text { Respect to } \\
\text { autonomy }\end{array}$ & $2.37 \pm 0.31$ & $3.43 \pm 0.27$ & $\begin{array}{l}\mathrm{T}=20.95 \\
P=.000^{* *}\end{array}$ & $3.24 \pm 0.34$ & $\begin{array}{l}\mathrm{T}=18.76 \\
P=.000^{* *}\end{array}$ \\
\hline Justice & $2.09 \pm 0.32$ & $2.58 \pm 0.23$ & $\begin{array}{l}\mathrm{T}=14.7 \\
P=.000^{* *}\end{array}$ & $2.50 \pm 0.20$ & $\begin{array}{l}\mathrm{T}=9.95 \\
P=.000^{* *}\end{array}$ \\
\hline Confidentiality & $2.66 \pm 0.30$ & $3.62 \pm 0.16$ & $\begin{array}{l}\mathrm{T}=20.73 \\
P=.000^{* *}\end{array}$ & $3.27 \pm 0.10$ & $\begin{array}{l}\mathrm{T}=15.53 \\
P=.000^{* *}\end{array}$ \\
\hline $\begin{array}{l}\text { Professional } \\
\text { responsibility }\end{array}$ & $2.74 \pm 0.15$ & $3.64 \pm 0.13$ & $\begin{array}{l}\mathrm{T}=35.01 \\
P=.000^{* *}\end{array}$ & $3.27 \pm 0.10$ & $\begin{array}{l}\mathrm{T}=7.84 \\
P=.000^{* *}\end{array}$ \\
\hline Total Mean & $2.44 \pm 0.20$ & $3.39 \pm 0.12$ & $\begin{array}{l}\mathrm{T}=35.01 \\
P=.000^{* *}\end{array}$ & $3.21 \pm 0.16$ & $\begin{array}{l}\mathrm{T}=26.6 \\
P=.000^{* *}\end{array}$ \\
\hline
\end{tabular}




\section{Results}

The Table 1 depicts the frequency and percentage distribution of nurses according to their demographic variables. With regard to the age $30(42.9 \%)$ were in the age group of more than 36 years. 21 (30\%) were working in Orthopedic unit, Most of them $64(91.4 \%)$ have Nursing diploma and the highest percentage $(67.1 \%)$ having experience ranged from 10-20 years.

Table 2 shows distribution of nurses according to their level of knowledge on ethical issues item wise and overall scorebefore, immediately post and after 3 months of program. It was observed that overall level of nurses' knowledge improved with the program as $(100 \%)$ of nurses had adequate knowledge immediately post program and three months later compared to only $59(84.3 \%)$ pre program. Also it is clear that the highest increase in nurses' knowledge immediately post and 3 month post program were related to autonomy, veracity and justice compared to preprogram respectively. Data in the same table illustrates also a decreased in nurses knowledge in relation to the majority of knowledge items three months after implementation of the program compared to immediately post program but still higher than pre program.

Table 4. Mean scores of nurses regarding frequency of stress of ethical issues during different periods of program $(\mathrm{N}=70)$

\begin{tabular}{|c|c|c|c|c|c|}
\hline \multirow{2}{*}{$\begin{array}{l}\text { Areas on Frequency of stress } \\
\text { of ethical issues }\end{array}$} & \multirow{2}{*}{$\begin{array}{l}\text { Pre program } \\
\text { Mean } \pm \text { SD }\end{array}$} & \multicolumn{2}{|c|}{ Immediately Post program } & \multicolumn{2}{|c|}{3 months Post program } \\
\hline & & Mean \pm SD & Paired ' $t$ '-value & Mean \pm SD & Paired ' $t$ '-value \\
\hline $\begin{array}{l}\text { Autonomy of the patient in the } \\
\text { accept or refuse treatment }\end{array}$ & $1.54 \pm 0.90$ & $2.69 \pm 0.47$ & $\begin{array}{l}\mathrm{T}=7.75 \\
P=.000^{* *}\end{array}$ & $2.51 \pm 0.50$ & $\begin{array}{l}\mathrm{T}=9.46 \\
P=.000^{* *}\end{array}$ \\
\hline $\begin{array}{l}\text { Breach of patient } \\
\text { confidentiality }\end{array}$ & $1.27 \pm 0.45$ & $2.69 \pm 0.47$ & $\begin{array}{l}\mathrm{T}=15.07 \\
P=.000^{* *}\end{array}$ & $2.51 \pm 0.50$ & $\begin{array}{l}\mathrm{T}=18.3 \\
P=.000^{* *}\end{array}$ \\
\hline $\begin{array}{l}\text { Unethical practices from the } \\
\text { health practitioner }\end{array}$ & $1.64 \pm 0.48$ & $2.0 \pm 0.0$ & $\begin{array}{l}\mathrm{T}=13.61 \\
P=.000^{* *}\end{array}$ & $1.69 \pm 0.47$ & $\begin{array}{l}\mathrm{T}=5.35 \\
P=.000^{* *}\end{array}$ \\
\hline Caring about patient rights & $1.54 \pm 0.79$ & $2.0 \pm 0.0$ & $\begin{array}{l}\mathrm{T}=4.82 \\
P=.000^{* *}\end{array}$ & $2.0 \pm 0.0$ & $\begin{array}{l}\mathrm{T}=4.82 \\
P=.000^{* *}\end{array}$ \\
\hline Advanced care planning & $1.51 \pm 0.50$ & $2.19 \pm 0.39$ & $\begin{array}{l}\mathrm{T}=8.91 \\
P=.000^{* *}\end{array}$ & $2.0 \pm 0.0$ & $\begin{array}{l}\mathrm{T}=3.97 \\
P=.000^{* *}\end{array}$ \\
\hline Alternative decision making & $1.0 \pm 0.0$ & $1.49 \pm 0.50$ & $\begin{array}{l}\mathrm{T}=0.341 \\
P=.73\end{array}$ & $1.46 \pm 0.50$ & $\begin{array}{l}\mathrm{T}=7.62 \\
P=.000^{* *}\end{array}$ \\
\hline $\begin{array}{l}\text { Make decisions concerning the } \\
\text { patient life }\end{array}$ & $2.66 \pm 0.76$ & $3.0 \pm 0.0$ & $\begin{array}{l}\mathrm{T}=2.54 \\
P=.01^{*}\end{array}$ & $2.91 \pm 0.28$ & $\begin{array}{l}\mathrm{T}=2.65 \\
P=.01^{*}\end{array}$ \\
\hline Protecting patient right & $1.83 \pm 0.38$ & $2.34 \pm 0.48$ & $\begin{array}{l}\mathrm{T}=0.962 \\
P=.34\end{array}$ & $1.90 \pm 0.51$ & $\begin{array}{l}\mathrm{T}=5.34 \\
P=0.000^{* *}\end{array}$ \\
\hline $\begin{array}{l}\text { Organ donation and } \\
\text { transplantation }\end{array}$ & $2.14 \pm 0.91$ & $3.0 \pm 0.0$ & $\begin{array}{l}\mathrm{T}=7.62 \\
P=.000^{* *}\end{array}$ & $0.0 \pm 3.0$ & $\begin{array}{l}\mathrm{T}=7.92 \\
P=.000^{* *}\end{array}$ \\
\hline $\begin{array}{l}\text { Medical research for } \\
\text { therapeutic innovation }\end{array}$ & $2.17 \pm 0.38$ & $2.49 \pm 0.50$ & $\begin{array}{l}\mathrm{T}=1.38 \\
P=.17\end{array}$ & $2.37 \pm 0.49$ & $\begin{array}{l}\mathrm{T}=2.77 \\
P=.02^{*}\end{array}$ \\
\hline Genetic testing and counselling & $2.31 \pm 0.96$ & $3.0 \pm 0.0$ & $\begin{array}{l}\mathrm{T}=7.63 \\
P=.000^{* *}\end{array}$ & $3.0 \pm 0.0$ & $\begin{array}{l}\mathrm{T}=6.00 \\
P=.000^{* *}\end{array}$ \\
\hline Distribution of resources & $2.17 \pm 0.38$ & $2.34 \pm 0.48$ & $\begin{array}{l}\mathrm{T}=1.40 \\
P=.17\end{array}$ & $2.20 \pm 0.71$ & $\begin{array}{l}\mathrm{T}=0.300 \\
P=.77\end{array}$ \\
\hline Conflicts of interest & $1.83 \pm 0.38$ & $2.26 \pm 0.44$ & $\begin{array}{l}\mathrm{T}=6.19 \\
P=.000^{* *}\end{array}$ & $2.0 \pm 0.0$ & $\begin{array}{l}\mathrm{T}=4.89 \\
P=.000^{* *}\end{array}$ \\
\hline $\begin{array}{l}\text { The conflict in the membership } \\
\text { of the profession }\end{array}$ & $2.0 \pm 0.0$ & $2.26 \pm 0.44$ & $\begin{array}{l}\mathrm{T}=4.89 \\
P=.000^{* *}\end{array}$ & $2.16 \pm 0.37$ & $\begin{array}{l}\mathrm{T}=1.74 \\
P=.15\end{array}$ \\
\hline $\begin{array}{l}\text { Patterns of nursing, which have } \\
\text { a negative effect }\end{array}$ & $1.0 \pm 0.0$ & $2.0 \pm 0.0$ & $\begin{array}{l}\mathrm{T}=8.55 \\
P=.000^{* *}\end{array}$ & $1.51 \pm 0.50$ & $\begin{array}{l}\mathrm{T}=2.62 \\
P=.000\end{array}$ \\
\hline Total & $2.01 \pm 0.14$ & $2.20 \pm 0.10$ & $\begin{array}{l}\mathrm{T}=8.86 \\
P=.000^{* *}\end{array}$ & $2.13 \pm 0.12$ & $\begin{array}{l}\mathrm{T}=5.71 \\
P=.000^{* *}\end{array}$ \\
\hline
\end{tabular}

Table 3 represents mean scores of nurses about ethical behavior preprogram, immediately post and post 3 months of program intervention. It is clear from this table that there was a highly statistical significant improvement in total mean score of nurses ethical behaviors immediately post and post 3 months of program intervention compare to pre pro- 
gram $\left(2.44 \pm 0.20,3.39 \pm 0.12, T=35.01, P=0.000^{* *}\right.$ and $\left.3.21 \pm 0.16, T=26.6, P=0.000^{* *}\right)$. Data in the same table also shows marked improvement in nurses ethical behavior in relation to both confidentiality and professional identity subscales as they had highest mean score immediately post and post 3 months of program intervention compare to pre program and it was proved to be highly statistical significant.

Table 4 represents mean scores of Nurses about frequency of stress, immediately post and post 3 months of program intervention. There was highly statistical significant difference in reduction of stress related to ethical stress after the teaching program. Also, there was highly statistical significant difference of nurses' frequency of stress toward making decisions concerning the patient life, protecting patient write and breach of patient confidentiality. The total mean scores of nurses frequency of stress pre program were $(2.01 \pm 0.14)$ and immediately post and 3 months post program were $(2.20 \pm 0.10,2.13 \pm 0.12)$ respectively.

Table 5 shows distribution of nurses according to their degree of stress pre, immediately post and post 3 months of program. It was observed that $(72.9 \%)$ had moderate level of stress of ethical issues in pre program whereas all had low level of stress of ethical issues immediately after the program and decreased to $82.9 \%$ after 3 months of the program.

Table 5. Distribution of nurses according to their degree of stress of ethical issues during different periods of program $(\mathrm{N}=70)$

\begin{tabular}{|c|c|c|c|c|c|c|}
\hline \multirow{2}{*}{$\begin{array}{l}\text { Degree of } \\
\text { Ethical } \\
\text { stress }\end{array}$} & \multicolumn{2}{|c|}{ Pre program } & \multicolumn{2}{|c|}{$\begin{array}{l}\text { Immediately Post } \\
\text { program }\end{array}$} & \multicolumn{2}{|c|}{$\begin{array}{l}3 \text { months Post } \\
\text { program }\end{array}$} \\
\hline & No & $\%$ & No & $\%$ & No & $\%$ \\
\hline High & 0 & 0 & 0 & 0 & 0 & 0 \\
\hline Moderate & 51 & 72.9 & 0 & 0 & 12 & 17.1 \\
\hline Low & 19 & 27.1 & 70 & 100 & 58 & 82.9 \\
\hline
\end{tabular}

Table 6 depicts the correlation between the frequency and degree of stress. The findings of the study shows that there is strong correlation $(r=0.835)$ between frequency and degree of ethical stress after the training program.

Table 6. Correlation between Frequency and Degree of Ethical Stress before (pre) and post program ( $\mathrm{N}=70)$

\begin{tabular}{llcc}
\hline S. No & Scores & $\begin{array}{l}\text { Frequency of } \\
\text { Ethical stress }\end{array}$ & $\begin{array}{l}\text { Degree of Ethical } \\
\text { stress }\end{array}$ \\
\hline 1 & Pre training & 0.34 \\
2 & Post training & $\begin{array}{c}0.835 \\
p \text {-value }=.000^{* *}\end{array}$ \\
\hline
\end{tabular}

Table 7 shows the correlation between Knowledge of Nursing ethics and the Frequency of ethical stress. The findings of the study suggests that there is strong correlation $(r=0.814)$ found between the Knowledge and frequency of ethical pres- sure after the training program.

Table 7. Correlation between knowledge scores of the study nurses and their scores about frequency of Ethical stress pre $\&$ post program intervention $(\mathrm{N}=70)$

\begin{tabular}{llll}
\hline S. No & Scores & $\begin{array}{l}\text { Knowledge of } \\
\text { Nursing Ethics }\end{array}$ & $\begin{array}{l}\text { Frequency of } \\
\text { Ethical Stress }\end{array}$ \\
\hline 1 & Pre training & 0.413 \\
2 & Post training & $\begin{array}{c}0.814 \\
p \text {-value }=.000^{* *}\end{array}$ \\
\hline
\end{tabular}

Table 8 illustrates the correlation between Knowledge of Nursing ethics and ethical behaviour. The above findings of the study shows that there is strong correlation $(r=0.635)$ between Knowledge of Nursing ethics and Ethical behaviour after the training program.

Table 8. Correlation between knowledge of Nursing ethics and Ethical behaviour pre \& post program intervention $(\mathrm{N}=$ 70)

\begin{tabular}{llcl}
\hline S.No & Scores & $\begin{array}{l}\text { Knowledge of } \\
\text { Nursing Ethics }\end{array}$ & $\begin{array}{l}\text { Ethical } \\
\text { Behaviour }\end{array}$ \\
\hline 1 & Pre training & 0.254 \\
2 & Post training & \multicolumn{2}{c}{0.635} \\
& & $p$-value $=.000^{* *}$ \\
\hline
\end{tabular}

The findings of the above Table 9 shows that there is no significant association found between Knowledge of Nurses on Nursing ethics, Ethical behaviour, Frequency of ethical stress with selected demographic variables.

\section{Discussion}

A nurse's knowledge and skill are important forces that can contribute to the power to influence patient care in an ethical manner. ${ }^{[27]}$

In this study, regarding level of nurses' knowledge about Nursing ethics pre and post 3 months of program, the research findings show that, overall level of Nurses' knowledge improved with the program immediately and after 3 months of program. It is inferred that the teaching program helped nurses to improve their knowledge in nursing ethics that confront nurses during their work settings related to ethical principles such as beneficence, consent, autonomy, veracity, justice, fidelity and confidentiality.

Studies show that ethics education can be effective in improving knowledge, confidence, and ethical behavior. Given the expanding role of advanced practice nurses as doctors of nursing practice, research is needed to determine the ethics knowledge needs and teaching strategies to better prepare nurses for the challenges of advanced practice. ${ }^{[28]}$

Also, Kumar et al. (2011) supported the findings of this 
study imply that there is a need for continued and intensified viding quality health care services, must acquire knowledge efforts to ensure that staff nurses, who are involved in pro- necessary about the legal and ethical issues and the effects of misuse of law and negligence of nursing practice. ${ }^{[29]}$

Table 9. Association between post training knowledge scores on Nursing Ethics, Ethical Behaviour and Frequency of Ethical Stress with their Demographic variables $(\mathrm{N}=70)$

\begin{tabular}{|c|c|c|c|c|c|c|c|c|c|c|c|c|c|c|c|}
\hline \multirow{3}{*}{$\begin{array}{l}\text { Demographic } \\
\text { variables }\end{array}$} & \multicolumn{4}{|c|}{$\begin{array}{l}\text { Post training knowledge } \\
\text { scores on Nursing } \\
\text { Ethics }\end{array}$} & \multirow{3}{*}{$\begin{array}{l}\chi^{2} \\
\text { Value }\end{array}$} & \multicolumn{4}{|c|}{$\begin{array}{l}\text { Post training knowledge } \\
\text { scores on Ethical Behaviour }\end{array}$} & \multirow{3}{*}{$\begin{array}{l}\chi^{2} \\
\text { Value }\end{array}$} & \multicolumn{4}{|c|}{$\begin{array}{l}\text { Post training knowledge } \\
\text { scores on frequency of } \\
\text { Ethical Pressure }\end{array}$} & \multirow{3}{*}{$\begin{array}{l}\chi^{2} \\
\text { Value }\end{array}$} \\
\hline & \multicolumn{2}{|c|}{ Adequate } & \multicolumn{2}{|c|}{$\begin{array}{l}\text { Non } \\
\text { Adequate }\end{array}$} & & \multicolumn{2}{|c|}{$\begin{array}{l}\text { High } \\
\text { Involvement }\end{array}$} & \multicolumn{2}{|c|}{$\begin{array}{l}\text { Low } \\
\text { Involvement }\end{array}$} & & \multicolumn{2}{|c|}{ Sometimes } & \multicolumn{2}{|c|}{ Seldom } & \\
\hline & No & $\%$ & No & $\%$ & & No & $\%$ & No & $\%$ & & No & $\%$ & No & $\%$ & \\
\hline \multicolumn{16}{|l|}{ Age (Years) } \\
\hline Less than 25 & 4 & 5.7 & 1 & 1.4 & \multirow{4}{*}{$\begin{array}{l}\chi^{2}=0.258 \\
P=.05\end{array}$} & 3 & 4.3 & 2 & 2.9 & \multirow{4}{*}{$\begin{array}{l}\chi^{2}=1.179 \\
P=.05\end{array}$} & 2 & 2.9 & 3 & 4.3 & \multirow{4}{*}{$\begin{array}{l}\chi^{2}=3.549 \\
P=.05\end{array}$} \\
\hline $25-30$ & 14 & 20 & 2 & 2.9 & & 13 & 18.6 & 3 & 4.3 & & 4 & 5.7 & 12 & 17.1 & \\
\hline $31-36$ & 17 & 24.3 & 2 & 2.9 & & 15 & 21.4 & 4 & 5.7 & & 5 & 7.1 & 14 & 20 & \\
\hline More than 36 & 27 & 38.6 & 3 & 4.3 & & 21 & 30 & 9 & 12.9 & & 10 & 14.3 & 20 & 28.6 & \\
\hline \multicolumn{16}{|l|}{$\begin{array}{l}\text { Department } \\
\text { Neurological }\end{array}$} \\
\hline Unit & 4 & 5.7 & 1 & 1.4 & \multirow{10}{*}{$\begin{array}{l}\chi^{2}=2.716 \\
P=.05\end{array}$} & 3 & 4.3 & 2 & 2.9 & \multirow{10}{*}{$\begin{array}{l}\chi^{2}=5.952 \\
P=.05\end{array}$} & 1 & 1.4 & 4 & 5.7 & \multirow{10}{*}{$\begin{array}{l}\chi^{2}= \\
11.438 \\
P=.05\end{array}$} \\
\hline ENT Unit & 4 & 5.7 & 1 & 1.4 & & 4 & 5.7 & 1 & 1.4 & & 2 & 2.9 & 3 & 4.3 & \\
\hline Surgical Unit & 12 & 17.1 & 2 & 2.9 & & 12 & 17.1 & 2 & 2.9 & & 2 & 2.9 & 12 & 17.1 & \\
\hline Orthopaedic Unit & 19 & 27.1 & 2 & 2.9 & & 17 & 24.3 & 4 & 5.7 & & 5 & 7.1 & 16 & 22.9 & \\
\hline Cosmetic Unit & 3 & 4.3 & 1 & 1.4 & & 2 & 2.9 & 2 & 2.9 & & 1 & 1.4 & 3 & 4.3 & \\
\hline Operating room & 3 & 4.3 & 1 & 1.4 & & 2 & 2.9 & 2 & 2.9 & & 2 & 2.9 & 2 & 2.9 & \\
\hline Casualty and & 11 & 15.7 & 2 & 2.9 & & 10 & 14.3 & 3 & 4.3 & & 4 & 5.7 & 9 & 12.9 & \\
\hline Emergency Unit & 1 & 1.4 & 0 & 0.0 & & 1 & 1.4 & 0 & 0.0 & & 0 & 0.0 & 1 & 1.4 & \\
\hline Infection control & 1 & 1.4 & 0 & 0.0 & & 1 & 1.4 & 0 & 0.0 & & 0 & 0.0 & 1 & 1.4 & \\
\hline $\begin{array}{l}\text { Cardio vascular } \\
\text { Unit } \\
\text { ICU new }\end{array}$ & 2 & 2.9 & 0 & 0.0 & & 2 & 2.9 & 0 & 0.0 & & 0 & 0.0 & 2 & 2.9 & \\
\hline \multicolumn{16}{|l|}{ Qualification } \\
\hline $\begin{array}{l}\text { Nursing technical } \\
\text { institute }\end{array}$ & 5 & 7.1 & 1 & 1.4 & \multirow{2}{*}{$\begin{array}{l}\chi^{2}=0.724 \\
P=.05\end{array}$} & 5 & 7.1 & 1 & 1.4 & \multirow{2}{*}{$\begin{array}{l}\chi^{2}=6.041 \\
P=.01\end{array}$} & 2 & 2.9 & 4 & 5.7 & \multirow{2}{*}{$\begin{array}{l}\chi^{2}=2.479 \\
P=.05\end{array}$} \\
\hline Nursing diploma & 57 & 81.4 & 7 & 10 & & 51 & 72.9 & 13 & 18.6 & & 11 & 15.7 & 53 & 75.7 & \\
\hline \multicolumn{16}{|l|}{ Experience Year } \\
\hline Less than 1 & 1 & 1.4 & 0 & 0.0 & \multirow{4}{*}{$\begin{array}{l}\chi^{2}=1.433 \\
P=.05\end{array}$} & 1 & 1.4 & 0 & 0.0 & \multirow{4}{*}{$\begin{array}{l}\chi^{2}=0.847 \\
P=.05\end{array}$} & 0 & 0.0 & 1 & 1.4 & \\
\hline $1-10$ & 8 & 11.4 & 1 & 1.4 & & 7 & 10.0 & 2 & 2.9 & & 4 & 5.7 & 5 & 7.1 & $\chi^{2}=2.929$ \\
\hline $10-20$ & 44 & 62.9 & 3 & 4.3 & & 37 & 52.9 & 10 & 14.3 & & 7 & 10.0 & 40 & 57.1 & $P=.05$ \\
\hline More than 20 & 11 & 15.7 & 2 & 2.9 & & 7 & 10.0 & 6 & 8.6 & & 5 & 7.1 & 8 & 11.4 & \\
\hline
\end{tabular}

In this respect Osingada et al. (2015) mentioned that, nurses should be adequately prepared to deal with the ethical challenges amidst the high workload and resource-constrained settings. Whereas nurses ethics is critical to the quality of nursing care, few has been documented about nurses' knowledge about ethics, their formal and in-service ethics training in developing countries. ${ }^{[30]}$

Turkmen and Savaser (2015) found that the majority of nurses wanted to learn about ethical codes. For this reason, he recommended that nurses working in clinics and future nurses in training be informed of the appropriate ethical behavior and codes. ${ }^{[31]}$

Trevino, et al. (2001) discussed that if employees are aware of ethical and legal issues, they will be more likely to ask the right questions and do the right thing when faced with an ethical dilemma. Employees can do the wrong thing simply because they are unaware or do not know where to go for assistance on difficult matters. ${ }^{[32]}$

Area wise analysis of Knowledge found that the highest increase in nurses knowledge immediately post and 3 months post program were related to autonomy, veracity and justice respectively.

Autonomy is the right of self-determination. ${ }^{[33]}$ It is the principle that guides many issues in the clinical setting, and is one that may only be overridden in exceptional circumstances. ${ }^{[34]}$ From the legal perspective, a person's right to autonomy is 
based on his or her competence or capacity to make a particular decision; however, determining competence can be problematic. ${ }^{[35]}$ In this respect Autonomy obligates healthcare professionals to grant others the freedom of will, and the freedom of action. This principle allows patients the personal liberty to participate in their own course of treatment, and make choices regarding their treatment plans.

Veracity is closely related to autonomy. This principle binds the healthcare provider and the patient to be truthful with each other and mutually share all pertinent information.

The principle of justice entails a fair and balanced distribution of healthcare services. ${ }^{[36]}$ Konishi (2009) also debates that conscious adult patients should decide themselves. With regard to nursing profession, nurses should provide the patients with information, explain suggested interventions, and let them free to either accept or reject oncoming procedures so that they and their families can make a decision about their condition. ${ }^{[37]}$

Regarding nurses ethical behaviors pre and post 3 months of program, the research findings show that, there was highly statistical significant in improvement of nurses ethical behaviors before and after the teaching program immediately \& 3 months of teaching. Data in the same Table 3 also shows marked improvement in nurses ethical behavior in relation to both confidentiality and professional identity subscales as they had highest mean score immediately post and post 3 months of program intervention compare to pre program and it was proved to be highly statistical significant.

This result suggests that nursing practice must be based on reliable evidence and nurse education must equip practitioners with the skills to challenge existing practices. Health professionals are likely to come into contact with patients taking part in clinical trials, and have a role to play in maintaining a culture of improving care using a strong evidence base. ${ }^{[38]}$

According to the American Medical Association (AMA) Education Service (2015), ethical behavior is not the display of one's moral rectitude in times of crisis. It is the day-to-day expression of one's commitment to other persons and the ways in which human beings relate to one another in their daily interactions. ${ }^{[39]}$

The result of the present study found that there was highly statistical significant difference in nurses' frequency of stress with the total mean scores of preprogram, immediately post and post 3 programs respectively. With regard to degree of stress it was observed that half of them had moderate level of stress of ethical issues in preprogram whereas all had low level of stress immediately after the program.
In this respect, Grady et al. (2009) stated that education and training in ethics has a significant effect on the confidence, use of ethics resources, and moral action of nurses. ${ }^{[19]}$

Ulrich and Grady (2009) mentioned objective of ethical issues that nurses experience across a range of clinical practice settings and the amount of stress these issues engender in the nurses. They also had drawn many important conclusions from their findings. Protection of patient rights is their most frequent ethical issue and staffing inadequacies as the most stressful issue. ${ }^{[40]}$

The result of the study indicates that there were strong correlation between Knowledge of Nursing ethics and Ethical behavior after the training program which means that by improving level of nurses' knowledge after program lead to increase Ethical behavior.

The findings were agreed with the findings of Aghdamet $e t$ al. (2013) show that, nursing profession needs knowledge of ethics to guide performance, significant relationwas found between nurses' knowledge of ethic codes and job satisfaction and complaint of ethical performance. ${ }^{[21]}$

Adams D, Miller BK. (2001) found there is a need for continuing education about ethical issues that enable nurses to use ANA code of ethics as a framework for action. ${ }^{[41]}$

In this respect, Iglesias and Vallejo (2014) stated that inadequate exposure to and/or inadequate knowledge of ethics in nursing education programs has been cited as contributing to poor socialization of nurses to their ethical responsibilities and a lack of commitment to ethics as a professional. The nurses think that ethic knowledge are required, guide nursing practice and identity also nurses who have a lack of experience not able to prevent patients from being harm. ${ }^{[42]}$

In addition the findings of the study suggest that there is strong correlation between the Knowledge and frequency of stress after the training program. This finding of study is supported by Johansson (2014). ${ }^{[43]}$

Study shows that, there were the relation between knowledge and stress. This study has sought to ascertain what nurses' experience as problematic ethical issues in nursing practice and how they have dealt with these issues. The findings of this study support overseas research suggesting that what concerns nurses most are not the so-called 'big' or 'exotic' issues of bioethics, such as abortion, euthanasia, organ transplantation, and reproductive technology which, significantly, were identified as being of least interest to the nurses surveyed. Rather, what is of most pressing concern to registered nurses (and the issues that cause them the most distress) are the frequently occurring issues of protecting patients' rights and 
human dignity, caring for patients in under resourced health care services (including staffing patterns that limit patient access to nursing care/managed care policies that threaten quality care), informed consent (including patient autonomy and family involvement in decision-making), providing care with possible risk to the nurses' own health (e.g. TB, HIV, violence, poor working conditions), ethical decision making, ethical issues at the end stages of life (e.g. prolonging the dying process using inappropriate means, not considering the patient's quality of life), working with an unethical, incompetent, or impaired colleague, and the use/nonuse of physical/chemical restraints.

The results of the study show that there is no significant association found between Knowledge of Nurses on Nursing ethics, Ethical behavior, Frequency of stress with selected demographic variables.

The study done by Ulrich et al. (2010) reported that there was statistical difference in ethical issues regarding age and years of experience. Younger nurses and with few years of experience reported an increased frequency of encountering ethical issues compare to experienced and senior nurses. ${ }^{[15]}$ In this study only $7.1 \%$ were less than 25 years and majority $67.1 \%$ had more than 10 to 20 years of experience.

\section{Conclusion}

There was a positive effect of an ethical issues teaching program on ethical knowledge, ethical behavior and ethical stress among nurses.

\section{RECOMMENDATION}

Every hospital must implement interdisciplinary strategies to recognize and identify the experience of ethical issues and ethical stress.

Hospital must create support systems and interdisciplinary forums to discuss patient goals of care, Employee assistance programs, Protocols for end-of-life care, Ethics committees, Critical stress debriefings, Grief counseling.

Ensure nurses' representation on institutional ethics committees with full participation in all decision making and to decrease ethical stress in the work environment.

Nurses must actively participate in professional activities to expand knowledge develop skill, understand the impact of ethical stress and implement strategies to accomplish desired changes in the work environment while preserving personal integrity and authenticity .

\section{Conflicts of InTEREST Disclosure}

The authors declare that they have no competing interests.

\section{REFERENCES}

[1] Deshpande S, Joseph J, Prasad R. Factors impacting ethical behavior in hospitals. Journal of Business Ethics. 2006; 69(2): 207-216. http://dx.doi.org/10.1007/s10551-006-9086-5

[2] ICHRN (2010): Nursing human resource planning and management competencies. International Center for Human Resource in Nursing. Available from: http: //www.hrhresourcescenter.org/node/ 3399

[3] WHO (2012): The WHO Global Competency Model. Available from: http://www.WHO.int/employment/whocompetencies _EN.pdF

[4] Poikkeus T, Nummienen O, Suhonen R, et al. A mixed method of systematic review: support of ethical competencies of nurses. JAN. 2013; 70(2): 256-271

[5] An Bord Altranais. Guidance to Nurses and Midwives Regarding Ethical Conduct of Nursing and Midwifery Research. 207. Available from: www.nursingboard.ie/GetAttachment.aspx?id

[6] Woods M. Nursing ethics education: are we really delivering the good(s)?. Nursing Ethics. 2005; 12(1): 5-18. http://dx.doi .org /10.1191/0969733005ne754oa

[7] Buelow JR, Mahan PL, Garrity AW. Ethical dilemmas as perceived by health care students with teaching implications. Journalof College Teaching and Learning. TLC. 2010; 7(2).

[8] Sinclair JM. New Zealand nursing students experiences of ethical issues in clinical practice. A Descriptive Study. Published Master Thesis. 2013.

Published by Sciedu Press
[9] Nightingale F. Notes on nursing: What it is and what it is not. Harrison \& Sons; 1st edition, London; 1859. p. 1-136 .

[10] Ulrich C, Zeitzer M. Ethical issues in nursing practice. In: Ravitsky V, Fiester A, Caplan A, editors. The Penn center guide to bioethics. Springer Publishing. 2009.

[11] Reinhardt C, Salsberry PL, Jennifer BS. Ethical Issues in nursing practice: Identifications and comparisons across clinical specialty. STTI International Nursing Research Congress. 2011. http: //hdl.handle.net/10755/153353

[12] Park H. Ethics issues in nursing practice. Journal of Nursing Law. 2009; 13(3): 68-7. http://dx.doi.org/10.1891/1073-7472 13.3 .68

[13] Christensen A. Legal and ethical issues confronting oncology nursing Seminars in Oncology Nursing. 2002; 18(2): 86-98.

[14] Redman BK, Fry ST. Nurses ethical conflict .What is really known about them? Nursing Ethics. 2000; 7(4): 360-366.

[15] Ulrich CH, Taylor C, Soeken KO, et al. Every day ethics. Ethical Issues and Stress in Nursing Practice. J Adv Nurse. 2010; 66(11): 1365-1377.

[16] Solum EM, Maluwa VM, Sevinsson E. Ethical problems in practice as experienced by Maluwa students nurses. Nursing Ethics. 2010; 19(1): 128-136. PMid:22140182 http://dx.doi.org/10.1177 /0969733011412106

[17] Park M, Kjervik D, Crandell J. The relationship of ethics education to moral sensitivity and moral reasoning skills of nursing 
students. Nurse Ethics. 2012; 19(4): 568-580. PMid:22691600 http://dx.doi.org/10.1177/0969733011433922

[18] Baykara ZG, Demir SG, Yaman S. The effect of ethical training on students recognizing ethical violation and developing moral sensitivity. Nursing Ethics. 2014: 1-15.

[19] Grady C, Danis M, Soeken K, et al. Does Ethics Education Influence the Moral Action of Practicing Nurses and Social Workers. Am J Bioeth. 2009; 8(4): 4-11.

[20] Silva M, Ludwick R. Ethics: Interstate Nursing Practice and Regulation: Ethical Issues for the 21st Century. Online Journal of Issues in Nursing. 1999; 4(2): 1. http://www . nursingworld.org/MainMenuCategories/AN AMarketplace/ANAPeriodicals/OJIN/Columns/Ethics/In terstateNursingPracticeandRegulation.htm

[21] Aghdam A, Hassankhani H, Zamanzadeh V, et al. Knowledge and Performance about Nursing Ethic Codes from Nurses' and Patients' Perspective in Tabriz Teaching Hospitals. Iran J Caring Sci. 2013; 2(3): 219-227.

[22] Canadian Nursing Association. Code of ethics for registered nurses. Centennial edition. 2008: 1-57.

[23] Morsy M. The Effectiveness of Implementing Clinical Supervision Models on Head Nurses' Performance and Nurses' Job Satisfaction at Benha University Hospital. Faculty of Nursing, Benha University; 2014. 68 p.

[24] Turk Hemsireler Dernegi (THD). Turkish nurse association, ethical principles and responsibilities for nurses. 2013. http://www . turk hemsirelerdernegi.org.tr/upload/hemsire/brosur.PDF

[25] Saglik B, Hasta HY. Patient's rights regulation. 1998. http://www.saglik.gov.tr/TR/dosya/1-19943/h/has tahaklariyonetmeligi.pdf

[26] Raines ML. Ethical decision-making in nurses: Relationships among moral reasoning, coping style, and ethics stress. JONAS Healthcare Law Ethics Regulation. 2000; 2(1): 29-41. PMid:10824015.

[27] Parker F. Ethics: The Power of One. Online Journal of Issues in Nursing. 2007; 13(1). http://www.nursingworld.org/MainM enuCategories/ANAMarketplace/ANAPeriodicals/OJIN/T ableofContents/vol132008/No1Jan08/Power.html

[28] Laabs C. Confidence and knowledge regarding ethics among advanced practice nurses. PubMed. 2012; 33(1): 10-4. http: //www . ncbi.nlm.nih.gov/pubmed/22416534

[29] Kumar R, Mehta S, Kalra R. Knowledge of staff nurses regarding legal and ethical responsibilities in the field of psychiatric nursing. Nursing and Midwifery Research Journal. 2011; 1(7): 1-11.
[30] Osingada C, Nalwadda G, Ngabirano T, et al. Nurses' knowledge in ethics and their perceptions regarding continuing ethics education: a cross-sectional survey among nurses at three referralhospitals in Uganda. 2015; 8(319). http://www.biomedcentral.com/1756 $-0500 / 8 / 319$

[31] Turkmen A, Savaser S. Pediatric Nurses' Information and Applications Related To Ethical Codes. Iran J Pediatr. 2015; 25(1): 321. ht tp://www.ncbi.nlm.nih.gov/pmc/articles/PMC4505979/

[32] Trevino L, Butterfield K, McCabe D. The ethical context in organizations: Influences on employee attitudes and behaviors. The Next Phase of Business Ethics. 2001; 3(1): 301-337. http: //dx.doi .o rg/10.1016/S1529-2096(01) 03018-8

[33] Beauchamp TL, Childress TE. Principles of biomedical ethics. 7th ed. New York, NY: Oxford university press. 2012.

[34] Cahill H, Holland S. Introducing Nursing Ethics: Themes in Theory and Practice. APS Publishing, Salisbury; 2004. p. 91-101.

[35] Dimond B. Legal Aspects of Nursing. Fifth edition. Churchill Livingstone, Edinburgh. 2005.

[36] Corning H. Ethical issues facing healthcare professionals. RCECS Educational Consulting Services, Inc. Unauthorized duplication is prohibited by law. 2005: 2-36. www.rcecs. com/MyCE/PDFDocs/c ourse/V7050.pdf

[37] Konishi E, Yahiro M, Nakajima N, et al. The Japanese value of harmony and nursing ethics. Nurs Ethics. 2009; 16(1): 625-36.

[38] Bowrey S, Thompson J. Nursing research: ethics, consent and good practice. Nursing times. 2014. http://www. nursingtimes.net /roles/nurse-educators/nursing-research-ethics-con sent-and-good-practice/5066949.fullarticle

[39] The American Medical Association (AMA) Education Service. Ethics and the Healthcare Professional. 2015.

[40] Ulrich C, Grady C. Doing "good" with limited resources: Is it good enough in the provision of quality clinical care? Clinical Scholars Review. 2009; 2(1): 5-7.

[41] Adams D, Miller BK. Professionalism in nursing behaviors of nurse practitioners. Journal of Professional Nursing. 2001; 17(1): 203-210.

[42] Iglesias M, Vallejo R. Nurse Attitudes in relation to health care ethics and legal regulations for nursing. J Actabioeth. 2014; 20(2): 255264. http://www.scielo.cl/scielo.php?pid=S1726-569X2 014000200013\&script=sci_arttext

[43] Johansson H. Stressors in Ugandan nurses' working-environment An observational study. 2014: 1-25. 